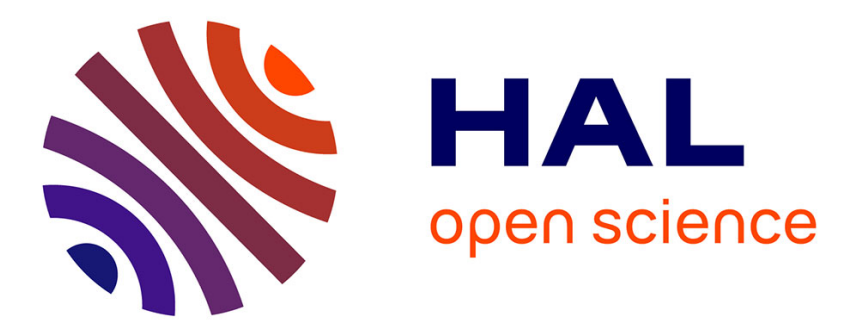

\title{
Phenoloxidase and peroxidase activities in Sphagnum-dominated peatland in a warming climate
}

\author{
Vincent E. J. Jassey, Geneviève Chiapusio, Daniel Gilbert, Marie-Laure
} Toussaint, Philippe Binet

\section{- To cite this version:}

Vincent E. J. Jassey, Geneviève Chiapusio, Daniel Gilbert, Marie-Laure Toussaint, Philippe Binet. Phenoloxidase and peroxidase activities in Sphagnum-dominated peatland in a warming climate. Soil Biology and Biochemistry, 2012, 46, pp.49-52. hal-00682547

\section{HAL Id: hal-00682547 https://hal.science/hal-00682547}

Submitted on 26 Mar 2012

HAL is a multi-disciplinary open access archive for the deposit and dissemination of scientific research documents, whether they are published or not. The documents may come from teaching and research institutions in France or abroad, or from public or private research centers.
L'archive ouverte pluridisciplinaire HAL, est destinée au dépôt et à la diffusion de documents scientifiques de niveau recherche, publiés ou non, émanant des établissements d'enseignement et de recherche français ou étrangers, des laboratoires publics ou privés. 
3 Vincent E.J. Jassey, Geneviève Chiapusio, Daniel Gilbert, Marie-Laure Toussaint and

$4 \quad$ Philippe Binet

5 Laboratoire Chrono-Environnement, UMR CNRS 6249, UFR Sciences, techniques et gestion

6 de l'industrie, Université de Franche-Comté, F-25211 Montbéliard cedex, France.

7

8

9

Correspondance to Philippe Binet

Laboratoire Chrono-Environnement, UMR CNRS 6249, UFR Sciences, techniques et gestion de l'industrie, Université de Franche-Comté, 4 place Tharradin, Montbéliard 25211 cedex,

13 France

Tel: +33 3819946 89; fax: +33381994661

E-mail address: philippe.binet@univ-fcomte.fr 
Peatlands still suffer from the scarcity of available data about the characterization and the response to climate forcing of the main oxidative enzymes that occur over the seasons. In the present study, phenoloxidase and peroxidase activities were examined in Sphagnum lawns along a narrow fen-bog gradient under experimental elevated temperatures. We showed that peroxidase activities from Sphagnum mosses were 1000-fold higher than those of phenoloxidases irrespective of seasons and sampling areas. Peroxidase activities increased (+ $30 \%$ ) with the rise of air temperatures (an average of $1^{\circ} \mathrm{C}$ ), while warming did not alter phenoloxidase activities. These results suggest that the monitoring of peroxidase activities in peatlands may represent a suitable and forward indicator of the impact of climate warming on carbon cycle in peatlands.

Keywords: 2,7-diaminofluorene; peroxidases; phenoloxidases; climate warming; peatland; open top chambers 
Extracellular phenoloxidase and peroxidase measurements in ecosystems provide essential information on the stability of the carbon cycle (Sinsabaugh, 2010; Theuerl et al., 2010). By contributing to the oxidation and transformation of both complex and simple phenolic compounds, these enzymes induce partial or complete degradation of such recalcitrant compounds, and finally act on carbon cycling (Baldrian, 2006; Sinsabaugh, 2010; Theuerl et al., 2010). Considering the ongoing global warming, these enzymes gain scientific concern in terrestrial carbon reservoirs, such as peatlands (Fenner et al., 2005; Laiho, 2006; Jassey et al., 2011b). The accumulation of carbon in peat soils is thought to partly result from a suppression of the normal pathways of enzymatic decomposition in which oxidative enzymes, such as phenoloxidases, play a key role (Freeman et al., 2001, 2004).

Although phenoloxidases (PO) involved in the degradation of polyphenols are divided into $\mathrm{PO}_{2}$ (e.g. laccases, tyrosinases) and $\mathrm{PO}_{2} \mathrm{O}_{2}$ (e.g. lignin and manganese peroxidases) dependent (Criquet et al., 2000a; Duran \& Esposito, 2000; Sinsabaugh et al., 2003, AlarcónGutiérrez et al., 2008; Sinsabaugh, 2010), only phenoloxidase $\mathrm{O}_{2}$ dependent have been predominantly investigated to date in peatlands. In forest litters, different spatiotemporal variations of $\mathrm{PO} \mathrm{O}_{2}$ and $\mathrm{H}_{2} \mathrm{O}_{2}$ dependent were recorded, emphasizing that all of these extracellular enzymes do not respond similarly to environmental changes (Criquet et al., 2000a; Duran and Esposito, 2000; Alarcón-Gutiérrez et al., 2008; Kaiser et al., 2010). Thus, peatlands suffer from the scarcity of available data about the characterization and the response to warming of these oxidative enzymes that occur over the seasons and ecological settings.

The purpose of the present paper was to determine the impact of an experimental climate warming on phenoloxidase activities $\mathrm{O}_{2}$ and $\mathrm{H}_{2} \mathrm{O}_{2}$ dependent in peatlands over two seasons along a transitional fen-bog gradient. Because our assays did not discriminate individual enzymes, the generic terms phenoloxidase and peroxidase were chosen to describe the activity of enzymes that use $\mathrm{O}_{2}$ and $\mathrm{H}_{2} \mathrm{O}_{2}$ as an acceptor, respectively. 
During field campaigns of summer and autumn 2010, peroxidases and phenoloxidases were investigated within a larger mire complex in fen and bog areas situated in the Jura Mountains (France, 46 49'35' N, 6 ${ }^{\circ} 10^{\prime} 20^{\prime}$ 'E). Sampling areas were situated along a transitional gradient between a poor fen and a raised bog with vegetation composition dominated by Sphagnum fallax (Jassey et al., 2011b). Samples of S. fallax were collected and cut into two levels: $0-3 \mathrm{~cm}$ (living segments $=$ Top) and 3-10 $\mathrm{cm}$ (early declining segments = Bottom) from the capitulum. In fen and bog areas, 6 Sphagnum plots were selected in representative surfaces including 3 replicates as ambient treatment and 3 replicates as warming treatment. The beginning of the warming treatment was on April 2008. Increasing of air temperature was passively achieved in warming plots using open-top chambers (hereafter referred as OTC) over the vegetation (Jassey et al., 2011b). Air temperatures (10 $\mathrm{cm}$ above Sphagnum surface) were monitored continuously in each plot.

Because soil organic matter could affect enzyme activities, a specific method of extraction was used (Criquet et al., 1999). $3 \mathrm{~g} \mathrm{FW}$ of $S$. fallax in $50 \mathrm{~mL} 0.1 \mathrm{M} \mathrm{CaCl}_{2}$ with $0.05 \%$ Tween 80 and 20 g PVPP were shaken for $1 \mathrm{~h}$. After centrifugation, the supernatant was filtrated $(0.2 \mu \mathrm{m})$ and concentrated in cellulose dialysis tubing (10 $\mathrm{kDa}$ molecular mass cut-off) covered with polyethylene glycol. Then, concentrated extracts were resuspended in phosphate buffer (pH 5.6) until 1/10 of the initial volume. Enzyme activities were measured by spectrophotometry using a 96 wells microtiter plate. For phenoloxidase quantification, each replicates wells contained $150 \mu \mathrm{L}$ of enzyme-extract with, either $100 \mu \mathrm{L}$ of L-DOPA (10 $\mathrm{mM}$ ), or $2 \mu \mathrm{L}$ of 2,7-diaminofluorene (DAF; $0.68 \mathrm{mM}$; $\varepsilon^{\mathrm{M}}=10228 \mathrm{M}^{-1} \cdot \mathrm{cm}^{-1}$ ), or $2 \mu \mathrm{L}$ of syringaldazine $\left(5 \mathrm{mM} ; \varepsilon^{\mathrm{M}}=65000 \mathrm{M}^{-1} . \mathrm{cm}^{-1}\right)$ or $5 \mu \mathrm{L}$ of ABTS $\left(0.1 \mathrm{mM} ; \varepsilon^{\mathrm{M}}=36000 \mathrm{M}^{-1} . \mathrm{cm}^{-}\right.$ ${ }^{1}$ ) in assay wells, and monitored at 460, 600, 525 and $420 \mathrm{~nm}$, respectively (Criquet et al., 2000a; Jassey et al., 2011b). Peroxidase activities were measured using $2 \mu \mathrm{L}$ DAF (0.68 mM) with $10 \mu \mathrm{L}$ of $\mathrm{H}_{2} \mathrm{O}_{2}(0.3 \%)$, and manganese peroxidases (Mn-peroxidases) with $12 \mu \mathrm{L}$ of $\mathrm{MnSO}_{4}(0.1 \mathrm{mM})$ (Criquet et al., 2001). Their oxidation rate was monitored at $600 \mathrm{~nm}$. 
Peroxidase activity was subtracted to the Mn-peroxidase assay to obtain the Mn-peroxidase activity. We also quantified fungal lignin-peroxidases using $12 \mu \mathrm{L}$ veratrylic alcohol (0.4 $\left.\mathrm{mM} ; \varepsilon^{\mathrm{M}}=9300 \mathrm{M}^{-1} \cdot \mathrm{cm}^{-1}\right)$ with $10 \mu \mathrm{L}$ of $\mathrm{H}_{2} \mathrm{O}_{2}(0.3 \%)$ and monitored at $310 \mathrm{~nm}$ in quartz cuvettes (Tien and Kirk, 1984). Enzymatic activities were expressed as one $\mu$ mol of substrate oxidized per minute per gram of dry mass $\left(\mathrm{U}_{\mathrm{g}} \mathrm{g}^{-1} \mathrm{DM}\right)$.

Differences of phenoloxidase and peroxidase pools between Sphagnum segments, sampling areas, seasons and climate treatments were analysed using repeated measures ANOVA with time as a within subject repeated factor (time $=2$ : Summer and Autumn) and warming treatment, area or sampling depth as between-subject factors. Interactions between sampling area, seasons and treatments were also considered. The assumptions of parametric tests were visualized and tested. An identical procedure was used to detect differences of air and soil temperatures between ambient and warming plots.

The highest values of phenoloxidase activities were recorded with DAF. Syringaldazine and ABTS substrates induced a formation of precipitates after $1 \mathrm{~h}$ of enzyme kinetic. Indeed, quinones produced from syringaldazine or ABTS were not soluble over time in aqueous medium (Floch et al., 2007). Phenoloxidase activities quantified with DAF showed significant differences along Sphagnum segments and between fen and bog ecological areas, whereas phenoloxidases quantified with L-DOPA did not change (Fig. 1). Therefore, the use of DAF is ideal to quantify phenoloxidases in Sphagnum peatlands.

We showed that peroxidases constituted the main oxidative system in Sphagnumpeatlands, with values of peroxidase activities 1000-fold higher than those of phenoloxidases (Figs 1 and 2). Although peroxidase activities 120-fold higher than phenoloxidase activities have been recorded in surface forest litter (Alarcón-Gutiérrez et al., 2009), peroxidases 1000fold greater than phenoloxidases is unique, to our knowledge (Sinsabaugh, 2010). Moreover, 
such ratio strongly suggested that peroxidases had a plant origin for several reasons. First, Sphagnum lawns largely dominate fen and bog areas. Second, DAF- $\mathrm{H}_{2} \mathrm{O}_{2}$ is known to be the most sensitive substrate for the detection of plant-peroxidases (Criquet et al., 2000b, 2001). Third, no fungal lignin-peroxidase activity was highlighted $\left(<10^{-7} \mathrm{U}_{\mathrm{g}}{ }^{-1} \mathrm{DM}\right)$, corroborating the Sphagnum origin of our high peroxidase activities. Furthermore, among the different fungus taxa identified in Sphagnum litter, few (only 24\%) are identified as phenoloxidase producers (Thormann et al., 2001). Abiotic conditions (e.g. acidic conditions and waterlogging) of peatlands are largely known to limit fungal oxidation activity (Williams et al., 2000; Toberman et al., 2008, 2010).

Significant decreased of peroxidases were recorded both along Sphagnum segments and over the seasons (ANOVA, $P<0.01$; Fig. 2). Such temporal variations suggest a positive relationship between peroxidase activities and polyphenol content. Jassey et al. (2011a, b) actually demonstrated that phenolic release from Sphagnum mosses changed over seasons, and decreased along Sphagnum shoots.

Warming by OTCs significantly increased the daily average air temperature (ANOVA, $P<0.001$ ) in both sampling areas (an average increase of $1{ }^{\circ} \mathrm{C}$ ). The increase of air temperatures also induce higher evapotranspiration in temperate zones, which result in lower Sphagnum moisture content during summertime (Jassey et al., 2011b). Despite this rise of air temperatures, phenoloxidase activities were not significantly influenced. Previous studies, which attempted to evaluate warming effect on phenoloxidases in peatlands, found equivocal results and concluded that the interactive effects of moisture and $\mathrm{pH}$ largely inhibited their oxidation activity (Toberman et al., 2010; Jassey et al., 2011b). On the contrary, the rise of air temperatures led to a significant increase of peroxidase activities in the fen area $(+30 \%)$, especially in living top segments (ANOVA, $P=0.017$; Fig. 2). The response of peroxidase activities to climate warming between the fen and bog areas also showed that oxidative pools change in different directions in response to climate warming, as already showed with 
phenolics (Jassey et al., 2011b). Although temperature was identified as an enhancer of

peroxidase activities, it still remains difficult to predict the effect of global warming on soil organic matter sequestration in peatlands because of multiple functions of peroxidases, both in mineralization and humification pathways (Sinsabaugh, 2010).

To conclude, our results point out that (i) the DAF is a relevant oxidative substrate to quantify both phenoloxidase and peroxidase activities in enzymatic extract from Sphagnum lawns, (ii) Sphagnum-peroxidase activities constituted the main oxidative system in Sphagnum-peatlands and (iii) the monitoring of plant-peroxidases represents a suitable and forward indicator of changes in carbon cycle in peatlands under a climate warming.

\section{Acknowledgements}

This research is a contribution of the ANR PEATWARM project (Effect of moderate warming on the functioning of Sphagnum peatlands and their function as carbon sink).

PEATWARM is supported by the French National Agency for Research under the Vulnerability: Environment-Climate Program (ANR-07-VUL-010). Further funding to VEJ Jassey by the Franche-Comté Region is kindly acknowledged.

\section{References}

Alarcón-Gutiérrez, E., Floch, C., Augur, C., Le Petit, J., Ziarelli, F., Criquet, S., 2009. Spatial variations of chemical composition, microbial functional diversity, and enzyme activities in a Mediterranean litter (Quercus ilex L.) profile. Pedobiologia 52, 387-399.

Alarcón-Gutiérrez, E., Couchaud, B., Augur, C., Calvert, V., Criquet, S., 2008. Effects of nitrogen availability on microbial activities, densities and functional diversities involved in the degradation of a Mediterranean evergreen oak litter (Quercus ilex L.). Soil Biology \& Biochemistry 40, 1654-1661.

Baldrian, P., 2006. Fungal laccases - occurrence and properties. Fems Microbiology Reviews 30(2): 215-242.

Criquet, S., Farnet, A. M., Tagger, S., Le Petit, J., 2000a. Annual variations of phenoloxidase activities in an evergreen oak litter: influence of certain biotic and abiotic factors. Soil 
Criquet, S., Joner, E., Leglize, P., Leyval, C., 2000b. Anthracene and mycorrhiza affect the activity of oxidoreductases in the roots and the rhizosphere of lucerne (Medicago sativa L.). Biotechnology Letters 22, 1733-1737.

Criquet, S., Joner, E. J., Leyval, C., 2001. 2,7-Diaminofluorene is a sensitive substrate for detection and characterization of plant root peroxidase activities. Plant Science 161, 1063-1066.

Criquet, S., Tagger, S., Vogt, G., Iacazio, G., Le Petit, J., 1999. Laccase activity of forest litter. Soil Biology \& Biochemistry 31, 1239-1244.

Duran, N., Esposito, E., 2000. Potential applications of oxidative enzymes and phenoloxidaselike compounds in wastewater and soil treatment: a review. Applied Catalysis B: Environmental 28: 83-99.

Fenner, N., Freeman, C., Reynolds, B., 2005. Hydrological effects on the diversity of phenolic degrading bacteria in a peatland: implications for carbon cycling. Soil Biology \& Biochemistry 37: 1277-1287.

Floch, C., Alarcon-Gutierrez, E., Criquet, S., 2007. ABTS assay of phenol oxidase activity in soil. Journal of Microbiological Methods 71, 319-324.

Freeman, C., Ostle, N., Kang, H., 2001. An enzymic 'latch' on a global carbon store - A shortage of oxygen locks up carbon in peatlands by restraining a single enzyme. Nature 409, 149-149.

Freeman, C., Ostle, N. J., Fenner, N., Kang, H., 2004. A regulatory role for phenol oxidase during decomposition in peatlands. Soil Biology \& Biochemistry 36, 1663-1667.

Jassey V.E.J., Gilbert D., Binet P., Toussaint M-L., Chiapusio, G., 2010a. Effect of a temperature gradient on Sphagnum fallax and its associated living microbial communities: a study under controlled conditions. Canadian Journal of Microbiology 57: 226-235.

Jassey, V.E.J., Chiapusio, G., Gilbert, D., Buttler, A., Toussaint, M.L., Binet, P., 2011 b. Experimental climate effect on seasonal variability of polyphenol/phenoloxidase interplay along a narrow fen-bog ecological gradient. Global Change Biology 17: 2945-2957.

Kaiser, C., Koranda, M., Kitzler, B., Fuchslueger, L., Schnecker, J., Schweiger, P., Rasche, F., Zechmeister-Boltenstern, S., Sessitch, A., Richter, A., 2010. Belowground carbon allocation by trees drives seasonal patterns of extracellular enzyme activities by altering microbial community composition in a beech forest soil. New Phytologist 187: 843-858.

Laiho, R., 2006. Decomposition in peatlands: Reconciling seemingly contrasting results on the impacts of lowered water levels. Soil Biology \& Biochemistry 38, 2011-2024.

Sinsabaugh, R. L., 2010. Phenol oxidase, peroxidase and organic matter dynamics of soil. Soil Biology \& Biochemistry 42, 391-404.

Sinsabaugh, R. L., Saiya-Corka, K., Long, T., Osgood, M. P., Neher, D. A., Zak, D. R., Norby, R. J., 2003. Soil microbial activity in a Liquidambar plantation unresponsive to 
Theuerl, S., Dorr, N., Guggenberger, G., Langer, U., Kaiser, K., Lamersdorf, N., Buscot, F., 2010. Response of recalcitrant soil substances to reduced $\mathrm{N}$ deposition in a spruce forest soil: integrating laccase-encoding genes and lignin decomposition. FEMS Microbiology Ecology 73, 166-177.

Tien, M., Kirk, T.K., 1984. Lignin-degrading enzyme from phanerochaete-chrysosporium purification, characterization, and catalytic properties of a unique $\mathrm{H}_{2} \mathrm{O}_{2}$-requiring oxygenase. Proceedings of the National Academy of Sciences of the United States of America-Biological Sciences 81, 2280-2284.

Toberman, H., Evans, C.D., Freeman, C., Fenner, N., Whiten M., Emmett, B.A., Artz, R.E.E., 2008. Summer drought effect upon soil and litter extracellular phenol oxidase activity and soluble carbon release in an upland Calluna heatland. Soil Biology \& Biochemistry 40, 1519-1532.

Toberman, H., Laiho, R., Evans, C.D., Artz, R.R.E., Fenner, N., Strakova, P., Freeman, C., 2010. Long-term drainage for forestry inhibits extracellular phenol oxidase activity in Finnish boreal mire peat. European Journal of Soil Science 61: 950-957.

Thormann, M.N., Currah, R.S., Bayley, S.E., 2001. Microfungi isolated from Sphagnum fuscum from a southern boreal bog in Alberta, Canada. Bryologist 104: 548-559.

Williams, C.J., Shingara, E.A., Yavitt, J.B., 2000. Phenol oxidase activity in peatlands in New York State: Response to summer drought and peat type. Wetlands 20: 416-421. 
226 Figure 1: Fungal phenoloxidase activities (mean \pm S.E.; $n=3$ ) characterized by DAF or L-

227 DOPA substrates along the fen-bog gradient of the Forbonnet peatland in summer and autumn 2282010 in different Sphagnum segments. Asterisks indicate significant differences of 229 phenoloxidase activities (ANOVA; $P<0.05$ ) between Sphagnum segments. Letters indicate 230 significant differences of phenoloxidase activities (ANOVA; $P<0.05$ ) between the fen and 231 the bog area. Top $=0-3 \mathrm{~cm}$; Bottom $=3-10 \mathrm{~cm}$ from capitulum.

Figure 2: Activity of peroxidases produced by Sphagnum (mean \pm S.E.; $\mathrm{n}=3$ ) along the fenbog gradient of the Forbonnet peatland in summer and autumn 2010 in different Sphagnum segments. Asterisks indicate significant differences of peroxidase activities (ANOVA; $P<$ 0.05) between Sphagnum segments. Letters indicate significant differences of peroxidase activities (ANOVA; $P<0.05$ ) between seasons (summer/autumn). Triangles $(\Delta)$ indicate significant differences between ambient and warming plots. Perox $=$ peroxidases $;$ Mn-perox $=$ manganese peroxidases. Top $=0-3 \mathrm{~cm}$; Bottom $=3-10 \mathrm{~cm}$ from capitulum . 